\title{
New information on the Critically Endangered Javanese Lapwing Vanellus macropterus, based mainly on unpublished notes by August Spennemann (c. 1878-1945)
}

\author{
S. (BAS) VAN BALEN and VINCENT NIJMAN
}

\section{Summary}

In a manuscript written by August Spennemann in the 1930s, information is presented on display behaviour, vocalizations and habitat at two hitherto unknown localities of the Javanese Lapwing Vanellus (Hoplopterus) macropterus, a species last recorded in 1940. We provide a translation of the notes and give a summary of all information additional to what has already been published on the species. The Javanese Lapwing is historically known from two discrete areas on the island of Java: one in the west along the north coast, and one in the east along the south coast. Spennemann's observations, made in 1927 and 1928 at Poponcol and Tegallurung, represent the last documented sightings of the species along the north coast and are situated some $75 \mathrm{~km}$ east of the north coast's previous easternmost known locality, effectively doubling the species' known range in western Java. At this time, the Javanese Lapwing was observed daily, and unlike at most other localities from where the species is known, was common. Spennemann observed them in groups of up to six birds, the largest group size recorded. Some local movement or migration is suggested by its erratic occurrence and off-shore sightings.

\section{Introduction}

The enigmatic and Critically Endangered Javanese Lapwing Vanellus (Hoplopterus) macropterus has not been recorded with certainty since 1940 and may be extinct (BirdLife International 2001; www.rdb.or.id). The species was confined to wide steppe-like marshes in river deltas and behind coastal sand dunes on the densely populated island of Java (Whitten et al. 1996) that currently is home to 124 million people at a density of almost 1 ,0oo persons $\mathrm{km}^{-2}$ (BPS 2006). The marshes have almost all been converted to paddyfields and shrimp ponds. All known records of Javanese Lapwing come from two discrete areas, $750 \mathrm{~km}$ apart: one in the west along the north coast, and one in the east along the south coast.

In April 2000 the Zoological Museum Amsterdam (ZMA) received a number of unpublished and previously virtually unknown notes and manuscripts, written by the German amateur ornithologist August Spennemann who lived on Java from c. 1915 to 1940. Among these is a detailed typed account of his observations of the Javanese Lapwing in the late 1920s near Pamanukan, West Java province.

August Spennemann (c. 1878-1945) lived during his Indonesian years mostly at Pegadenbaru, some $30 \mathrm{~km}$ to the south of the area described below (Hoogerwerf 1948), but at the time of the lapwing observations he resided in Bandung; after 1930 he reportedly lived at Parakansalam near Purwakarta, until he was interned by the Dutch in May 1940, and later died in an allied prison camp in then British India (van Steenis-Kruseman 1950). Part of his library and field notes were 
confiscated after his internment and presented to the Zoological Museum of Bogor. This included part of his collection of ornithological field notes, which around 1939 had been submitted by Spennemann for publication to the editors of the annual reports of the Dutch East Indian Society for Conservation (Hoogerwerf 1948).

In this paper we present distributional and biological data that are additional to previous accounts published on the Javanese Lapwing (Hayman et al. 1986, Piersma and Wiersma 1996, Whitten et al. 1996, Collar et al. 2000, BirdLife International 2001). In addition we compare these data with other historical accounts of the species; all translations are ours.

\section{Spennemann's notes}

The Appendix gives a translation of the German text found amongst the numerous notes written by Spennemann and deposited in Amsterdam. Between July 1927 and January 1928 he observed the Javanese Lapwing in abandoned paddyfields near Poponcol and Tegallurung (Pamanukan district, Subang regency), in the deltas of a number of rivers, generally referred to as the Muara Bobos area (Fig. I). Poponcol is located some $75 \mathrm{~km}$ east of Kali Pisangan, the easternmost locality along the north coast from where the Javanese Lapwing was hitherto known (BirdLife International 2001). Spennemann observed the lapwings as singletons, pairs, and groups of four to six. The lapwings were clearly resident in the area in the period July to August (Poponcol) and December to January (Tegallurung), when Spennemann observed them nearly each time he visited the area. However, during an earlier report on a 3-day survey in the Ciasem delta in the same general area in May-June 1916 not a single lapwing was observed by him (Spennemann

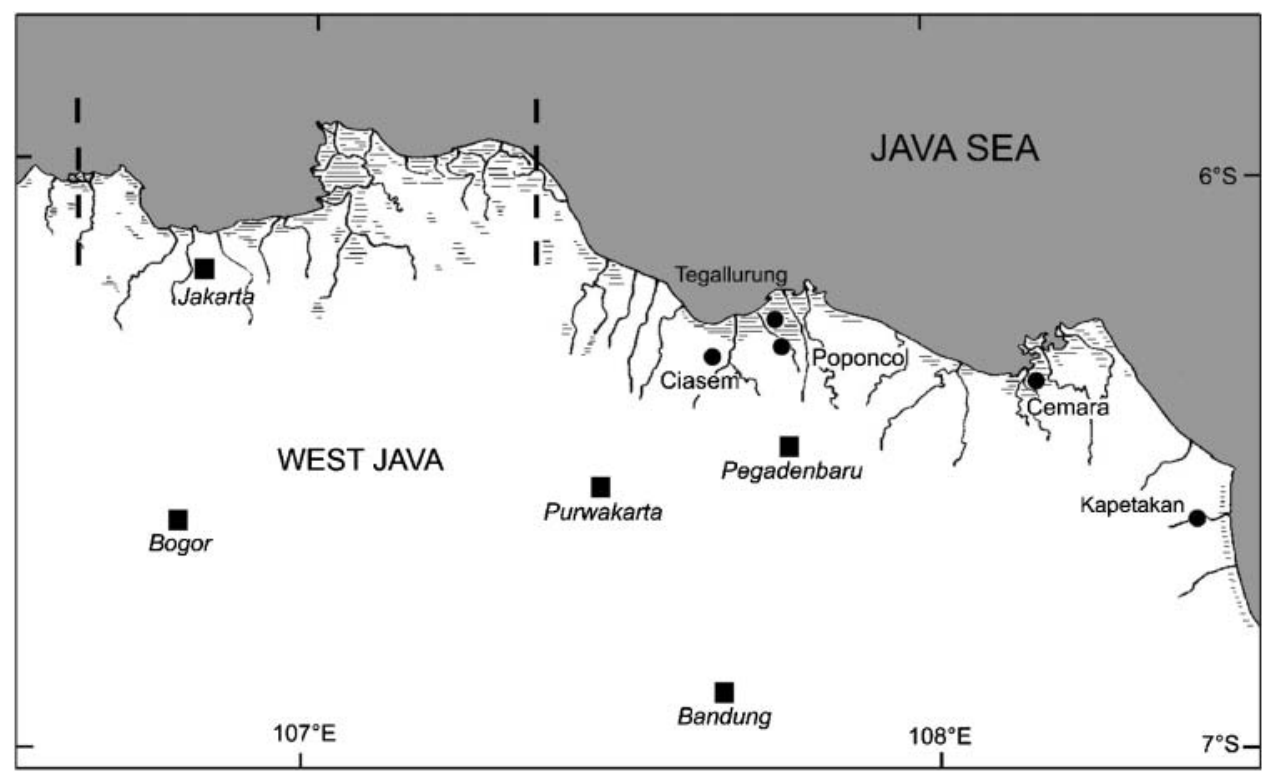

Figure I The distribution of coastal swamps as present in the 1930s (after Anonymous 1938, Hoogerwerf and Rengers Hora Siccama 1938) with localities of Javanese Lapwing mentioned in the text. The area between the dashed lines indicates the coastal region from where all previous records originated (note that for two localities - Tangerang and Karawang - the name of the regency is the same as its main town; in BirdLife International (2001) the locations of the main towns are mapped, whereas we map the coastal and swampy parts of the regency). A single female in the Zoological Museum Bogor is labelled Buitenzorg (= Bogor). 
1924). Especially interesting is the detailed description of the birds' vocalizations and behaviour, which is, and most likely will remain, the only information that is known on this species.

The observations by Spennemann are valuable for a number of reasons. From a conservation perspective we discuss aspects of (i) the species' distribution and habitat use, (ii) flocking behaviour and breeding biology, including seasonality, (iii) field characters and vocalizations, and (iv) recent surveys and potential areas where the Javanese Lapwing might still occur.

\section{Distribution and habitat}

In its south-eastern range the species has been reported from three localities - south Yosowilangun, Meleman and Lake Kejotangon ("Danau Kedjotangon") (Kooiman 1938; BirdLife International 2001) - with the most recent records dating back to April 1939. As a result of their close proximity, Yosowilangun and Meleman $(5.9 \mathrm{~km}$ in a straight-line distance) most likely refer to one and the same locality, but is unclear where the lake was or is situated. All three, however, are almost certainly in the grassland, dune and swamp area that is shaped and intersected by the Semangga, Bondoyudo, Besini and Bedadung rivers which flow into the sea in this area.

The north-western cluster of records comprises some ten localities along a $100 \mathrm{~km}$ stretch of coastline (note that there is also a bird in the Zoological Museum of Bogor that is labelled Buitenzorg [= Bogor]; this town is situated some $50 \mathrm{~km}$ south of this coastal belt). Spennemann's notes show that, as of 1929, the Javanese Lapwing was still regularly encountered along Java's north coast. In fact, it could be the most recent record for the western cluster where the last birds were collected in January 1927 (a female now in ZMA). A clutch of two Javanese Lapwing eggs collected in June 1940 (BirdLife International 2001) was presented to the National Natural History Museum (Naturalis), Leiden by A. Hoogerwerf; however, it is not clear how Hoogerwerf obtained these eggs and what the source is for the date and locality ascribed to them. Hoogerwerf never observed the Javanese Lapwing himself (and therefore it is unlikely that he would have collected the eggs), as in his unpublished manuscript on Javan birds, currently stored in ZMA, finalized in 1946 and updated in 1965, he wrote "We never observed this species in the wild" (Hoogerwerf 1965: 86).

Hoogerwerf (1965) describes the habitat of "the race atronuchalis, living on the Asian mainland" (i.e. with reference to the Red-wattled Lapwing Vanellus indicus), although elsewhere he considers the Javanese Lapwing as a monotypic species. Interestingly, Red-wattled Lapwing is mentioned for Java in the catalogue of the bird collection of Naturalis, but the skin (RMNH 27749) is missing (R. Dekker, in litt. 1995). The bird was collected by F. C. van Heurn, on 30 September 1925 at Kapetakan, Cirebon, West Java (Fig. 1) outside the Javanese Lapwing's known range but well within its potential range. The possibility that the bird was in fact a Javanese Lapwing should not be excluded, given the above-mentioned taxonomic confusion by his contemporary, A. Hoogerwerf, but more so because no lapwing other than the Javanese has been added to the list of Javanese avifauna.

Spennemann saw the lapwings in a diverse anthropogenic landscape of fallow paddyfields and fishponds, bordered by mangroves, a habitat which is still abundant throughout its range. Furthermore, it seems that the species was a common resident in the area, as he observed them very regularly. Moreover, all previous records of the species refer to single birds or pairs that are found spread out over large areas, and the observation of a group of six is the largest on record. Finally, Spennemann's observations indicate that the range along Java's north coast was considerably larger than might be assumed from the evidence to date. As the coastal swamp area between the westernmost localities and Pamanukan (and possibly even further eastwards to Cemara and Kapetakan: see previous paragraph and next section) was occupied by the lapwing at the beginning of the twentieth century, the historical range of the Javanese Lapwing in western Java might actually have been twice or more the size of its hitherto known range. 


\section{Seasonality}

Bartels never saw the lapwings in flocks, and the sighting of six lapwings in January as described by Spennemann may be quite exceptional (Collar et al. 200o). Whether Spennemann's observation represents a higher local density, or flocking in the non-breeding season, will most likely never be established. The laying season is reported as May-June (seven clutches) (Hellebrekers and Hoogerwerf 1967, Collar et al. 2000).

All western Javan localities known for lapwings are in the driest parts of Java (see van Steenis 1972) with strong seasonal differences in rainfall. Bartels (in BirdLife International 2001) reported the lack of territoriality of lapwings and their almost complete absence in the Citarum delta in December 1923. In terms of rainfall, December 1923 was normal (256 mm vs $203 \mathrm{~mm}$ on average) but the preceding months were very dry. Unusual lack of rainfall may also explain the absence of lapwings from the Ciasem delta in May 1916 (rainfall $53 \mathrm{~mm}$ vs $162 \mathrm{~mm}$ on average) but not their departure from Poponcol in August 1927 (rainfall $37 \mathrm{~mm}$ vs $32 \mathrm{~mm}$ on average; all rain data from G. J. van Oldenborgh in litt. 2005). Combined, the absence of lapwings during certain months but their presence in others as observed by knowledgeable observers suggests a local seasonal movement. If the lapwings are seasonally absent from certain areas this might explain the following account from the nineteenth century by Vorderman (1885): "When I made a sea voyage in 1872 from Pamanukan to Batavia [= Jakarta] on the steamer Coquette, off Tjamara $[=$ Cemara $]$ in the evening several of these lapwings landed on the railing of the forward deck of the boat, so that they could be taken by hand; this happened while we could see the north coast of Java." Unfortunately no month was mentioned by Vorderman.

On a smaller scale, the seasonality of rice cultivation may play a role in the seasonal absence of lapwings: the same area of several square kilometres can be essentially shallow open water, waist-high dense vegetation or dry stubble at any time of the year, as irrigation allows three rice crops a year regardless of the season, which renders the presence of lapwings in any of these habitats unpredictable (N. Brickle in litt. 2006).

Although migration movements between Sumatra ${ }^{1}$ and Timor as reported by Temminck (1838 in King 1978-1979) ${ }^{2}$ have been considered almost certainly erroneous (Hayman et al. 1986, BirdLife International 2001) the lapwing's extraordinarily long wings (hence the specific name macropterus) clearly indicate a powerful flight and local (migratory) movements remain possible (Schlegel 1865, Collar et al. 2000, BirdLife International 2001). Alternatively, it has been suggested that the historical range of this shorebird represents a relict distribution, and that Sumatra and Timor were once part of its global range, which urges the historical records from those islands to be re-considered (J. Eames in litt. 2006). Whilst the untimely disappearance of the species from the relatively untouched Sumatra, Timor and Borneo, rather than from the over-populated island of Java, is unexpected, the suggestion fits with the Pleistocene landscape of low sea-levels during which a number of species of a monsoonal avifauna and typical of swamp margins thrived in the huge river delta on the Sunda shelf (Yaffle 1985), beyond their present range, and of which relict populations exist on Java, Sumatra and the south-east corner of Borneo. Timor, however, does not appear in this scenario.

Kooiman $(1938,1940)$ reports the lapwing as "present throughout the year in several pairs in meadows along the swamps along the south coast", and, in November 1936, "whilst approaching the exit of the area, several lapwings, screaming loudly, showed us out." The latter behaviour may suggest territoriality in the non-breeding season in East Java, apparently different from the western population, although this population occurs in the same strongly seasonal climate (van Steenis 1972).

\footnotetext{
${ }^{1}$ Vorderman (1890: 415) includes Sumatra, Borneo and Java in its range.

${ }^{2}$ Van Marle \& Voous 1988 (86): "One specimen and one egg allegedly from Sumatra lacking further data, but may have been collected by S. Müller (RMNH - Schlegel 1865: 68, Vorderman 1890: 415, GF Mees)".
} 


\section{Field characters and vocalizations}

Whilst 'modern' descriptions of the lapwing tend to represent it as a rather dull-looking dark bird, descriptions by Vorderman of a freshly killed bird, and by Spennemann of live birds, show us clearly that the lapwing must have been a stunning bird. The contrast-rich grey, white and yellow plumage, proud upright stance and elegant gait contributed to this. The wattles of the lapwing are described as white with a dark tip (Vorderman 1885), pale creamy (Hayman et al. 1986; however, their plate shows faded yellow wattles) or flesh-coloured (Hoogerwerf 1965) to yellow (Piersma and Wiersma 1996). However, the paler versions of the description may be based on post-mortem fading of colour. Spennemann describes bright yellow wattles in a busily calling and presumably agitated bird. The legs are variably described as greenish yellow to orangey yellow (Hayman et al. 1986). More precisely Vorderman (1885; and partly taken over by Koningsberger 1909) describes the legs as "extraordinarily beautifully coloured: the naked part of the tibia is fiery orange to near the tarsus, where it changes downward into bright yellow. The scales of the front of the tarsus and upper part of the toes are dark sepia; a dirty yellow web unites the base of the outer toe with the middle toe."

The wing spurs are described as black, slightly curved thorns of $1.5-2 \mathrm{~cm}$, particularly hard and well developed in the breeding season (Koningsberger 1909, Hoogerwerf 1965), to yellow (Hoogerwerf 1965). The latter description may refer to a non-breeding or juvenile condition.

Local names, such as terek (Horsfield 1821), beberèk (Bartels in Koningsberger 1909) and errek-errek or errek-errekan (Spennemann), all have clearly onomatopoeic origins. Hoogerwerf (1965) gives kenanga as one of the lapwing's local names, but without mentioning its source. The name kenanga is also used for a well-known native tree, Canangium odoratum, which is often cultivated for its greenish or yellowish, very fragrant flowers (Merrill 1949). The relation to the lapwing, however, is obscure. The Bronze-winged Jacana Metopidius indicus, also rare on Java, is sometimes called burung kenaga (MacKinnon 1988), but this could be a typo for burung kenanga, whereas its superficial similarity to the Javanese Lapwing (e.g. Koningsberger 1915) could have caused confusion with the latter. Kenaga has no particular meaning, unless it is a corrupted version of the Old Javanese/Sanskrit word kenaka (or kanaka), a "polite" form of $k u k u$, meaning nail, or claw (Pigeaud 1938), which could then refer to the bird's wing spur; or the Sanskrit word kanaka, meaning gold (e.g. in the Cirebon dialect of Javanese; see Sudjana 2001), which would then refer to the golden yellow legs and wattles of the lapwing (but not the jacana, which has no yellow-coloured body parts). Local people who have been interviewed and had first-hand experience with Javanese Lapwings appeared to be well aware of the species' uniqueness (e.g. Tamrin et al. 2003). The word kenaka belongs to the Krama Inggil vocabulary, an extremely polite usage in the Javanese language that is used for only a limited number of bird species (I. Supriyanto in litt. 2005). However, the name might reflect the people's high esteem of the bird, because of its rarity and/or unique wing spurs.

Although he never saw them in the wild, Hoogerwerf (1965) describes the lapwing's vocalization as "a plaintive calling, usually uttered in flight, and well reflected by the local name duit-duit or minta-duit". The source(s) of both this vocalization and the local names could not be traced. Spennemann describes a number of different calls, most of which are of rattling quality, reminiscent of toy trumpets, and often given during the evening. None of these, however, coincides with the calls reported by Hoogerwerf. The Appendix gives the details of the context in which these calls are given.

1. Calls of busily "gesturing" bird standing on a higher point in an open landscape: "t $[r] e t$ $t[r]$ et $t[r]$ et $t[r]$ ett $[r] t ! "$ sounding like the sound of a toy trumpet, with faintly audible " $r$ "s; and then it goes like: "tät tät tät tät - - tähhhhht!" which is alternated again with "trrrek - terrrr!" or also just "trrrrrrr!".

2. Very different from first calls "trètrètrètrètrèt!" or also "trrrrrähhht!"; both calls sound rattling. 
3. Calls preceding taking off: a repeated "krähhh!" and "ähhh!"; also "trähhhhwü!" has been heard before taking off.

4. Flight call: an angry "krihhh!".

5. A non-rattling call "tetetititit!"; this is perhaps the same, or about the same as, the oftenrepeated, quite rapid "tititititititi", uttered in group context.

Although analysis of vocalizations of birds based on transcription is difficult and treacherous, especially where descriptions by different authors are concerned, after close comparison it appears that the Javanese Lapwing's calls resemble those of the Australian Masked Lapwing $V$. miles (1, staccato "krik-krik-krik"; 2, sharp "kek"; 3, slurred, repeated "kreerk-kreerk") rather than the other possibly related wattled and/or spur-winged lapwings, including the Red-wattled Lapwing, although their calls reportedly recall those of the Masked Lapwing (Hayman et al. 1986).

\section{Present status}

Searches during the past two decades, in particular in areas where the lapwing was historically found (Citarum delta, West Java; south Lumajang, East Java) or where seemingly suitable habitat was present, have failed to record the species (e.g. Bowler et al. 1984, Allport and Wilson 1986, Milton and Marhadi 1989, BirdLife International 2001, S. v. B. unpubl. data; BirdLife International - Indonesia Programme unpubl. data). However, there have been unconfirmed reports of single birds between 1999 and 2003 seen near Tanjung Air (Muara Gembong), where good habitat still remains (Tamrin et al. 2003). In February 1986 one of us (S. v. B.), and in July 2006 N. Brickle (in litt. 2006), made cursory visits to the Muara Bobos area north of Pamanukan, i.e. in the same general area as Spennemann's observations. The area was established as protection forest (hutan lindung) in 1915, and a nature reserve (cagar alam) of 1,000 ha (Scott 1989) to 5,000 ha (MacKinnon et al. 1982) has been proposed for the mangroves that still survive. The Javanese Lapwing was not observed, and a large part of the habitat appeared to have been converted into fish ponds and intensive rice cultivation (currently three crops per year), leaving some scattered patches of mangroves but little "natural" grassland. The Pamanukan and Tegallurung observations indicate that potentially suitable habitat could still be present away from the formerly known range of the lapwing. However, the levels of disturbance may not allow the lapwings to breed (N. Brickle in litt. 2006).

BirdLife International (2001) believes that "the disturbance and conversion of its wet-grass savanna habitat ... was the principal agent of its disappearance", aggravated by its naturally low density and hence susceptibility to extinction. However, Spennemann's account suggests that its habitat choice might have been (and hence might still be) less narrow. Because of this, and the apparently seasonal character of its occurrence, which reduces the chance of finding the birds at apparently suitable habitat, we hope by means of this note to encourage conservationists and birders to continue the exploration of potential lapwing areas. Prime target areas for future surveys are the estuaries of Muara Gembong and Tanjung Sedari (north-east of Jakarta), those undersurveyed estuaries of Muara Bobos (north-west of Poponcol) and Muara Cimanuk (north-east of Cemara) in the west, and the area south of Lumajang in the east of Java. Furthermore, several other swampy areas scattered around Java and yet to be selected might be worth surveying.

\section{Appendix. Translation of Spennemann's notes on the Javanese Lapwing}

Our annotations are given in square brackets.

\section{Lobivanellus cucullatus (Temm.)}

On one of the last July days in 1927, [Mr] van Aken and I drove from Pamanukan to Poponcol, which was the first time for me. Near the fallow paddyfields, bordering the mangrove, and which 
since the last harvest were covered in reed and swamp plants, I saw several Javanese Lapwings, which persistently chased a Haliastur intermedius [Brahminy Kite Haliastur indus] and also a crow, and also stooped onto him. Until about 1o August, [I] was able to observe the same scenario several times over; later, however, not anymore. Whether the lapwings had left the area, or whether they had no reason anymore to chase away robbers that threaten their brood, I cannot decide.

\section{September 1927}

An Erek-erek stands on a mound of earth in the middle of the paddy swamp, and rattles off a part of its musical repertoire; first he calls awhile:

"t(r)et $\mathrm{t}(\mathrm{r}$ )et $\mathrm{t}(\mathrm{r})$ et $\mathrm{t}(\mathrm{r})$ ett $(\mathrm{r}) \mathrm{t} !$ ", with the " $\mathrm{r}$ " in parentheses only just audible; and then it goes like: "tät tät tät tät - - tähhhhht!" which is alternated again with "trrrek - terrrr!" or also just "trrrrrrr!" Everything sounds rather hoarse, a bit like the sound of a toy trumpet. Whilst calling, the bird turns around first to one side, then the other. Often it walks several steps forward, stands suddenly still, looks around, picks up something, turns [and] walks further in another direction, picks up something again, and so on. Its stance is proud and upright. The bright yellow wattles are striking.

\section{2 to 29 December 1927}

Behind the last house of Tegallurung this morning already I saw two lapwings, called errekerrek or errek-errekan by the Sundanese, and tonight two stand on the dyke of a fish pond and call continuously; they really are distinguished birds! This proud, upright stance, every movement elegant, and they are not shy at all here: at a distance of only $20 \mathrm{~m}$ they let themselves be quietly observed with field glasses.

When standing or moving the black head and upper neck is conspicuous, the nice grey back and the yellow legs; when they stoop to pick up food and they turn their back towards us, then the snow-white under-tail coverts shine visibly from afar. From time to time they take off for short flights; also now they can be described with certainty: head and upper neck black, the back and upper wing, in contrast with the black flight feathers, show a nice grey-brown and the tail, of which the upper [= proximal $]$ half looks white and the lower [ = distal $]$ half black, is adorned with a white streak, which shows up especially well when the bird flies up with fanned tail.

The flight of the lapwing over a longer distance, when not startled and when not intending to chase away an unwelcome guest in its breeding territory, is also distinguished by slow, rowing, but rather rapidly propelling wing beats.

The voice is very different. Mostly I heard at this time: "trètrètrètrètrèt!" or "trrrrrähhht!"; both calls sound rattling. Another time I heard in the evening from a single lapwing, standing on a paddyfield dyke: "krähhh!" After this it flew away slowly. Another bird, which I had observed for a long time on the morning of 27 December 1929, had first called several times "krähhh!" and "ähhh!" and had then often looked around left and right to me, and made ready to take off, and when it indeed at last flew away, it uttered an angry (or so it sounded to me) "krihhh!" when flying. Another produced, also in the evening, before taking off, "trähhhhwü!" And on 29 December I heard, besides the already-mentioned "trrähhht!", a "tetetititit!".

All calls, except for the last one, sound rattling, and are reminiscent of the sound of a toy trumpet, but do not sound unpleasant.

Until the end of January I saw the lapwing almost every time I passed the paddyfields.

\section{January 1928}

A lapwing calls continuously a quite rapid "tititititititi", however not as creaking as usual, so that I first thought it was another bird, then still again quite creaking "trrrrrr!"; another 
answers; there are four which have gathered. Two birds stand in the middle, quite ducked, their bodies in a horizontal position, so that bill, head, neck and back form a straight line. I believe these are the females; the two others stand at each side of the central group in proud, upright stance and call. When 2 hours later I pass this place again in the jukung [= dug-out], I saw the same (?) [bird] there still ? or again?

\section{January 1928}

Today I saw at about the same place as on 26 January a gathering of six lapwings. They crowded close to each other, on a patch of ground of not more than perhaps a square meter and gave a concert, in which they produced all the sounds that they had at their disposal. When I drew myself up in the boat, however, they flew away.

\section{Acknowledgements}

Thanks go to the Indonesian Institute for Sciences (LIPI) and the Directorate General for Forest Protection and Nature Conservation (PHKA) for providing us with permits to conduct our fieldwork in Indonesia, and to Joko Iskandar (Padjadjaran University, Bandung) as team leader of 1986 coastal survey. Thanks go also to Geert Jan van Oldenborgh (KNMI) for meteorological information and Ignatius Supriyanto (Leiden University) for linguistic comments. Nigel Collar, Jonathan Eames and Nick Brickle reviewed the final manuscript and provided valuable comments.

\section{References}

Allport, G. A. and Wilson, S-A. (1986) Results of a census of the Milky Stork Mycteria cinerea in West Java. Cambridge, U.K.: International Council for Bird Preservation. (Study Report 14).

Anonymous (1938) Atlas van tropisch Nederland. Amsterdam: Koninklijk Nederlands Aardrijkskundig Genootschap.

BirdLife International (200I) Threatened birds of Asia. Part A. Cambridge U.K: BirdLife International.

Bowler, J., Howes, J. and Long, A. (1984) Wader observations in the north-coast of Java. Pp. 143-149 in Interwader Annual Report. Kuala Lumpur: Interwader. (Interwader Publication 2).

BPS (Badan Pusat Statistik) (2006) Population statistics. www.bps.go.id [accessed 14 Aug 2006].

Collar, N. J., Scharlemann, J. P. W. and Fisher, C. T. (2000) Max E. G. Bartels and the Javan Lapwing Vanellus macropterus. Kukila 11: 122-124.

Hayman, P., Marchant, J. and Prater, T. (1986) Shorebirds. An identification guide to the waders of the world. London and Sydney: Croom Helm.
Hellebrekers, W. Ph. J. and Hoogerwerf, A. (1967) A further contribution to our zoological knowledge of the island of Java (Indonesia). Zoologische Verhandelingen 88: 1-164.

Hoogerwerf, A. (1948) Ter nagedachtenis. Chronica Naturae 104: 1-3.

Hoogerwerf, A. (1965) Vogels van Java. Unpublished manuscript lodged at the Department of Birds, Zoological Museum Amsterdam.

Hoogerwerf, A. and Rengers, G. F. H. W. Hora Siccama (1937-1938) De avifauna van Batavia en omstreken. Ardea 26: 1-51, 116-159; 27: 41-92, 179-246.

Horsfield, T. (1821) Systematic arrangement and description of birds from the island of Java. Trans. Linn. Soc. Lond. 13: 133-200.

King, W. B. (1978-1979) Red data book 2: Aves. Second edition. Morges, Switzerland: International Union for Conservation of Nature and Natural Resources.

Koningsberger, J. C. (1909) De vogels van Java en hunne oeconomische betekenis. Batavia: Kolff.

Koningsberger, J. C. (1915) Java, zoölogisch en biologisch. Buitenzorg: Departement van Landbouw, Nijverheid en Handel. 
Kooiman, J. G. (1938) Excursie-verslag van de Afd. Besoeki naar de kuststrook ten z. Van Loemadjang. De Tropische Natuur 27: 126-130.

Kooiman, J. G. (1940) Mededeelingen over het voorkomen in Oost-Java van enkele voor dit gewest nog niet in de literatuur genoemde vogels. Ardea 29: 98-108.

MacKinnon, J., Smiet, F. and Artha, M. B. (1982) A national conservation plan for Indonesia. Volume III: Java and Bali. Bogor: FAO.

MacKinnon, J. (1988) Field guide to the birds of Java and Bali. Yogyakarta: Gadjah Mada University Press.

Merrill, E. D. (1949) De plantengroei van de Maleise Archipel. Leiden: Sijthoff.

Milton, R. and Marhadi, A. (1989) An investigation into the market-netting of birds in West Java. Bogor: PHPA and WWF/IUCN.

Piersma, T. and Wiersma, P. (1996) Family Charadriidae (Plovers). Pp. 384-442 in J. del Hoyo, A. Elliott and J. Sargatal, eds. Handbook of the birds of the world. Volume 3 . Hoatzin to auks. Barcelona: Lynx Edicions.

Pigeaud, T. (1938) Javaans-Nederlands handwoordenboek. Groningen, Batavia: Wolters.

Schlegel, H. (1865) Revue méthodique et critique des collections déposées dans cet établissement. Volume 7(3). Cursores. Leyden: Muséum d'Histoire Naturelle des Pays-Bas.

Scott, D. A. (1989) A directory of Asian wetlands. Gland, Switzerland and Cambridge, U.K. IUCN.
Spennemann, A. W. (1924) Moeara Tjiasem, 29 Mei - 2 Juni 1916. De Tropische Natuur 13: $173-176$.

Sudjana, T. D. (2001) Kamus Bahasa Cirebon. Bandung: Humaniora Utama Press.

Tamrin, Z., Lestiyanto, T., Hardianto, N., Nandika, D. Herna (2003) Survei keberadaan Trulek Jawa Vanellus macropterus di Bekasi, Jawa Barat. Unpublished report. van Marle, J. G. and Voous, K. H. (1988) The birds of Sumatra. Tring, U.K.: British Ornithologists' Union. (BOU Check-list 10).

van Steenis, C. G. G. J. (1972) The mountain flora of Java. Leiden: Brill.

van Steenis-Kruseman, M. J. (1950) Malaysian plant collectors and collections being a cyclopaedia of botanical exploration in Malaysia and a guide to the concerned literature up to the year 1950. Djakarta: Noordhoff-Kolff.

Vorderman, A. G. (1885) Bataviasche vogels. Part 6. Natuurkundig Tijdschrift voor Nederlandsch-Indië 44: 208-253.

Vorderman, A. G. (1890) Les oiseaux de Sumatra et leur présence dans les îles avoisinantes. Natuurkundig Tijdschrift voor Nederlandsch-Indië 49: 381-442.

Whitten, T., Soeriaatmadja, R. E. and Afiff, S. A. (1996) The ecology of Java and Bali. Singapore: Periplus Editions.

Yaffle $(=$ D. A. Holmes) (1985) Ornithological reflections: the Thai connection. Voice of Nature 28: 13-15.

\section{S. (BAS) VAN BALEN*}

Department of Animal and Plant Sciences, Sheffield University, Alfred Denny Building, Western Bank, Sheffield, U.K.

\section{VINCENT NIJMAN}

Zoological Museum, University of Amsterdam, P. O. Box 94766, 1090 GT Amsterdam, The Netherlands.

*Author for correspondence. Current address: Roompotstraat 44, 6826 EP Arnhem, The Netherlands; e-mail: bvanbalenoo1@hotmail.com 